L. Hetland Grant/research support from: AbbVie, Biogen, BMS, Celtrion, Eli Lilly Denmark A/S, Janssen Biologics B.V, Lundbeck Fonden, MSD, Pfizer, Roche, Samsung Biopis, Sandoz. MLH chairs the steering committee of the Danish Rheumatology Quality Registry (DANBIO), which receives public funding from the hospital owners and funding from pharmaceutical companies. MLH co-chairs the EuroSpA research collaboration, which generates real-world evidence of treatment of psoriatic arthritis and axial spondyloarthritis based on secondary use of quality data and is partly funded by Novartis., Johan Askling: None declared, Tanja Schjødt Jørgensen: None declared, Lene Dreyer Speakers bureau: Eli-Lilly and Galderma, Grant/research support from: BMS, Dan Nordström: None declared, Brigitte Michelsen: None declared, Arni Jon Geirsson: None declared, Lennart T.H. Jacobsson: None declared, Bente Glintborg Grant/research support from: Abbvie, BMS, Pfizer, Lundbeck foundation

DOI: 10.1136/annrheumdis-2021-eular.630

\begin{tabular}{|l|l|}
\hline OP0141 & EFFECTS OF FILGOTINIB ON SPINAL LESIONS IN \\
& ANKYLOSING SPONDYLITIS: MAGNETIC \\
& RESONANCE IMAGING DATA FROM THE TORTUGA \\
& TRIAL
\end{tabular}

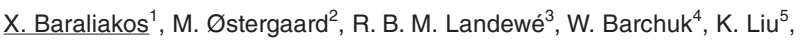
C. Tasset ${ }^{6}$, L. Gilles ${ }^{7}$, T. Hendrikx ${ }^{8}$, R. Besuyen ${ }^{9}$, W. P. Maksymowych ${ }^{10} .{ }^{1}$ RuhrUniversity Bochum, Rheumazentrum Ruhrgebiet, Herne, Germany; ${ }^{2}$ University of Copenhagen, Copenhagen Center for Arthritis Research, Rigshospitalet, Copenhagen, Denmark; ${ }^{3}$ Maastricht University Medical Center, Department of Rheumatology, Maastricht, Netherlands; ${ }^{4}$ Gilead Sciences, Inc., Inflammation Clinical Research, Foster City, United States of America; ${ }^{5}$ Gilead Sciences, Inc., Biostatistics, Foster City, United States of America; ${ }^{6}$ Galapagos NV, Late Stage Development, Mechelen, Belgium; ${ }^{7}$ Galapagos NV, Clinical Research, Mechelen, Belgium; ${ }^{8}$ Galapagos BV, Medical Affairs, Leiden, Netherlands; ${ }^{9}$ Galapagos BV, Clinical Research, Leiden, Netherlands; ${ }^{10}$ University of Alberta, Department of Medicine, Division of Rheumatology, Edmonton, Canada

Background: The oral Janus kinase 1 preferential inhibitor filgotinib (FIL) significantly improved Spondyloarthritis Research Consortium of Canada (SPARCC) magnetic resonance imaging (MRI) inflammation scores (bone marrow oedema) in the spine and sacroiliac joints vs placebo (PBO) in the Phase 2 TORTUGA trial (NCT03117270) in patients with active ankylosing spondylitis (AS). ${ }^{1}$

Objectives: This post-hoc analysis evaluated the effects of FIL on Canada-Denmark (CANDEN) MRI measures of spinal inflammation and structural lesions in patients from the TORTUGA trial.

Methods: TORTUGA was a PBO-controlled, multicentre, double-blind, randomised trial. Patients with active AS (as per modified New York classification criteria, with sacroiliitis confirmed by central reading) were treated with FIL $200 \mathrm{mg}(\mathrm{n}=58)$ or PBO $(n=58)$ once daily for 12 weeks. MRI of the total spine was conducted at baseline and at treatment end. Scans were re-evaluated post-hoc by 2 independent experts (blinded to time point and assigned treatment) using the CANDEN method ${ }^{2}$ inter-reader discrepancies were resolved by an independent adjudicator. Observed changes from baseline were evaluated using analysis of covariance, with factors for treatment, baseline value, and randomisation stratification by prior tumour necrosis factor inhibitor use. Least-squares (LS) mean changes from baseline and between-group differences with $95 \%$ confidence intervals $(\mathrm{Cl})$ were calculated; $P$ values are nominal.

Results: MRI scans from 88 patients (47 FIL, 41 PBO) with an evaluable scan at baseline and Week 12 (or early termination) were re-evaluated. Baseline characteristics were generally similar between patients with/without an MRI scan. Of those with MRI scans, mean total spine inflammation score (which ranges from 0-614) was higher, and mean ankylosis score (which ranges from 0-460) was lower, in the FIL vs PBO group at baseline. Total spine inflammation scores decreased from baseline with FIL but not with PBO (Figure and Table; $\mathrm{P}=0.0003$ for between-group difference). Cumulative probability plots favoured FIL over PBO for change from baseline in subregion inflammation scores, including posterolateral elements (i.e. sum of lesions in ribs, transverse processes, spinous processes, soft tissue inflammation, and postero-lateral vertebral body), facet joint, and vertebral body. Total spine fat lesion scores numerically increased from baseline in the FIL but not PBO group $(\mathrm{P}=0.0878$ for between-group difference; Table). There were no significant differences between groups for changes in erosion $(P=0.1956)$ or ankylosis $(P=0.3888)$ scores (Table).
Table 1. Change from baseline at Week 12 in CANDEN total spine inflammation, total spine fat, total spine bone erosion, and ankylosis scores

\begin{tabular}{|c|c|c|c|c|c|c|c|c|}
\hline & $\begin{array}{l}\text { Treatment } \\
\text { group }\end{array}$ & $\mathbf{n}$ & $\begin{array}{c}\text { Sample } \\
\text { mean } \\
\text { (SE) }\end{array}$ & $\begin{array}{c}\text { LS } \\
\text { mean } \\
(\mathrm{SE})\end{array}$ & $\begin{array}{c}95 \% \mathrm{Cl} \text { of } \\
\text { treatment } \\
\text { mean }\end{array}$ & $\begin{array}{l}\text { LS mean } \\
\text { of group } \\
\text { difference } \\
\text { (SE) }\end{array}$ & $\begin{array}{c}95 \% \mathrm{Cl} \\
\text { of group } \\
\text { difference }\end{array}$ & $\begin{array}{c}\text { Between- } \\
\text { group } \\
\text { P value }\end{array}$ \\
\hline \multirow[t]{2}{*}{$\begin{array}{l}\text { Total spine } \\
\text { inflamma- } \\
\text { tion score }\end{array}$} & Filgotinib & 47 & $\begin{array}{c}-4.98 \\
(0.96) \\
0.29\end{array}$ & $\begin{array}{c}-4.40 \\
(1.13) \\
0.09\end{array}$ & $\begin{array}{l}-6.65 \\
-2.15\end{array}$ & $\begin{array}{l}-4.49 \\
(1.21)\end{array}$ & $-6.85,-2.12$ & 0.0003 \\
\hline & Placebo & 41 & $(0.78)$ & $(1.13)$ & $-2.17,2.34$ & & & \\
\hline \multirow[t]{2}{*}{$\begin{array}{l}\text { Total spine } \\
\text { fat score }\end{array}$} & Filgotinib & 47 & $\begin{array}{c}1.01 \\
(0.62) \\
-0.25\end{array}$ & $\begin{array}{c}1.09 \\
(0.66) \\
-0.09\end{array}$ & $-0.22,2.40$ & $\begin{array}{c}1.18 \\
(0.69)\end{array}$ & $-0.18,2.55$ & 0.0878 \\
\hline & Placebo & 41 & $\begin{array}{c}(0.19) \\
0.01\end{array}$ & $\begin{array}{c}(0.66) \\
0.07\end{array}$ & $-1.40,1.21$ & 0.05 & & \\
\hline \multirow{2}{*}{$\begin{array}{l}\text { Total spine } \\
\text { bone } \\
\text { erosion } \\
\text { score }\end{array}$} & Filgotinib & 47 & $\begin{array}{l}(0.02) \\
-0.02\end{array}$ & $\begin{array}{c}(0.03) \\
0.02\end{array}$ & $0.00,0.14$ & $(0.04)$ & $-0.02,0.12$ & 0.1956 \\
\hline & Placebo & 41 & $(0.03)$ & $(0.03)$ & $-0.04,0.09$ & & & \\
\hline \multirow[t]{2}{*}{$\begin{array}{l}\text { Total } \\
\quad \text { ankylosis } \\
\text { score }\end{array}$} & Filgotinib & 47 & $\begin{array}{c}0.30 \\
(0.29) \\
-0.01\end{array}$ & $\begin{array}{c}0.23 \\
(0.31) \\
-0.06\end{array}$ & $-0.40,0.85$ & $\begin{array}{l}0.28 \\
(0.34)\end{array}$ & $-0.37,0.94$ & 0.3888 \\
\hline & Placebo & 41 & $(0.08)$ & $(0.31)$ & $-0.68,0.56$ & & & \\
\hline
\end{tabular}

SE, standard error

Conclusion: This is the first PBO-controlled trial to demonstrate a decrease in inflammatory activity with FIL, not only in the spinal vertebrae but also in the postero-lateral elements of the spine and facet joints. As expected in a 12-week study period, no changes in erosion or ankylosis were seen, while fat lesions showed a tendency to increase with FIL. Larger trials are needed to confirm these results.

REFERENCES:

[1] van der Heijde D, et al. Lancet 2018;392:2378-87.

[2] Krabbe S, et al. RMD Open 2019;5:e001057.

Acknowledgements: The TORTUGA trial was sponsored by Galapagos NV (Mechelen, Belgium) and co-funded by Galapagos NV and Gilead Sciences, Inc. (Foster City, CA, USA). Medical writing support was provided by Debbie Sherwood BSc, CMPP (Aspire Scientific Ltd, Bollington, UK), and funded by Galapagos NV.

Figure. Change from baseline in total CANDEN spine inflammation score

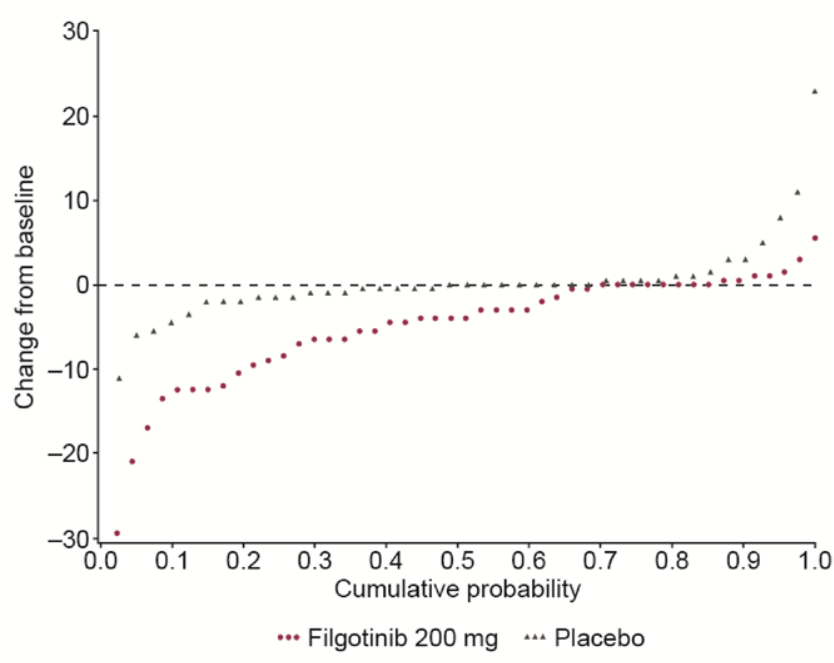

CANDEN, Canada-Denmark

Disclosure of Interests: Xenofon Baraliakos Consultant of: AbbVie, Bristol Myers Squibb, Celgene, Chugai, Eli Lilly, Galapagos, Hexal, Janssen, MSD, Novartis, Pfizer, Sandoz and UCB, Grant/research support from: AbbVie, Celgene, Novartis and UCB, Mikkel Østergaard Speakers bureau: AbbVie, Boehringer Ingelheim, Bristol Myers Squibb, Celgene, Eli Lilly, Hospira, Janssen, Merck, Novartis, Orion, Pfizer, Roche, Sandoz, Sanofi and UCB, Consultant of: AbbVie, Boehringer Ingelheim, Bristol Myers Squibb, Celgene, Eli Lilly, Hospira, Janssen, Merck, Novartis, Novo Nordisk, Orion, Pfizer, Regeneron, Roche, Sandoz, Sanofi and UCB, Grant/research support from: AbbVie, Bristol Myers Squibb, Celgene, Merck and Novartis, Robert B.M 
Landewé Speakers bureau: AbbVie, Amgen, Bristol Myers Squibb, Janssen (formerly Centocor), Merck, Pfizer, Roche, Schering and UCB, Consultant of: AbbVie, Ablynx, Amgen, AstraZeneca, Bristol Myers Squibb, Celgene, Eli Lilly, Galapagos, Gilead, GlaxoSmithKline, Janssen, Merck, Novartis, Novo Nordisk, Pfizer, Roche, Schering, TiGenix and UCB, Grant/research support from: AbbVie, Amgen, Janssen (formerly Centocor), Novartis, Pfizer, Roche, Schering and UCB, Employee of: Director of Rheumatology Consultancy BV, William Barchuk Shareholder of: Gilead Sciences, Inc., Employee of: Currently employee of Gilead Sciences, Inc.; and former employee of AbbVie, Eli Lilly and Johnson \& Johnson, Ke Liu Shareholder of: Gilead Sciences, Inc., Employee of: Gilead Sciences, Inc., Chantal Tasset Shareholder of: Galapagos, Employee of: Galapagos, Leen Gilles Employee of: Galapagos, Thijs Hendrikx Shareholder of: Galapagos, Employee of: Galapagos, Robin Besuyen Shareholder of: Galapagos, Employee of: Galapagos, Walter P Maksymowych Speakers bureau: AbbVie, Janssen, Novartis, Pfizer and UCB, Consultant of: AbbVie, Boehringer Ingelheim, Celgene, Eli Lilly, Galapagos, Gilead, Janssen, Novartis, Pfizer and UCB, Grant/research support from: AbbVie, Novartis, Pfizer and UCB, Employee of: Chief Medical Officer of CARE Arthritis Limited

DOI: 10.1136/annrheumdis-2021-eular.1797

\section{OP0142 NETAKIMAB REDUCES ANKYLOSING SPONDYLITIS ACTIVITY IN PATIENTS WITH OR WITHOUT SACROILIITS ON MRI: RESULTS OF SUBANALYSIS OF PHASE 3 ASTERA TRIAL}

1. Gaydukova ${ }^{1,2}$, V. Mazurov' ${ }^{1}$ S. Erdes ${ }^{3}$, T. Dubinina ${ }^{4}$, A. Kundzer $^{5}$ N. Soroka ${ }^{6}$, A. Eremeeva ${ }^{7} .{ }^{1}$ Mechnikov North-Western State Medical University, Department of Therapy and Rheumatology of Temporary Disability and Medical Care Quality Expertise, St-Petersburg, Russian Federation; ${ }^{2}$ Clinical Rheumatology Hospital No 25, Consultative Outpatient Department, St-Petersburg, Russian Federation; ${ }^{3}$ Nasonova Research Institute of Rheumatology, Laboratory of Spondyloarthritides, Moscow, Russian Federation; ${ }^{4}$ Nasonova Research Institute of Rheumatology, Laboratory of Medical and Social Problems of Rheumatology, Moscow, Russian Federation ${ }^{5}$ Belarusian Medical Academy of Postgraduate Education, Department of Cardiology and Rheumatology, Minsk, Belarus; ${ }^{6}$ Belarusian State Medical University, Department of Internal Diseases №2, Minsk, Belarus; ${ }^{7} J$ SC BIOCAD, Clinical Development Department, St-Petersburg, Russian Federation

Background: The presence of sacroiliitis in patients (pts) with ankylosing spondylitis (AS) on imaging can be established both by sacroiliac joint (SIJ) $\mathrm{X}$-ray or MRI. Active sacroiliitis on MRI as defined by ASAS is predictor of good treatment response to biological disease modifying anti-rheumatic drugs [1, 2]. Netakimab (NTK) is a humanized anti-interleukin-17A antibody approved for the treatment of AS, psoriatic arthritis, moderate-to-severe plaque psoriasis in Russia and Belarus. The difference in treatment response to NTK in AS pts with and without active sacroiliitis on MRI (MRI+/ MRI-) is unclear.

Objectives: To report the changes in AS activity in pts with and without sacroiliitis on MRI at week 16 of NTK treatment.

Methods: ASTERA (NCT03447704) is an ongoing phase 3 placebo (PBO)-controlled clinical study, aimed at evaluating NTK efficacy in AS. All pts fulfilled modified New York criteria. Evaluation of acute inflammation on SIJ MRI was performed at the baseline but was not an inclusion criterion. This analysis includes pts received subcutaneous NTK $120 \mathrm{mg}$ every 2 wks with available baseline SIJ MRI. The presence of sacroiliitis on MRI was defined as SPARCC >2. Efficacy endpoints included ASAS20/40, ASAS partial remission (PR), changes from baseline in BASDAI (Bath Ankylosing Spondylitis Disease Activity Index), ASDAS-CRP (Ankylosing Spondylitis Disease Activity Score).

Results: $67 \mathrm{MRI}+$ and $46 \mathrm{MRI}-$ pts were included into analysis. Baseline characteristics were balanced across both arms. $42.4 \%$ of MRI+ pts and $38.3 \%$ of MRI- pts achieved ASAS40 at week 16 ( $p \geq 0.05)$, ASAS20 was observed in $65.2 \% / 55.3 \%$ pts in the same arms respectively $(p \geq 0.05)$. ASAS PR was reported for $15.2 \% \mathrm{MRI}$ and $17.0 \% \mathrm{MRI}-\mathrm{pts}(\mathrm{p} \geq 0.05)$. Improvements in BASDAI and ASDAS-CRP were similar across both arms. At wk 16, mean change from baseline in BASDAI was -2.7 vs -3.0 for MRI+ and MRI- pts respectively, mean change in ASDAS-CRP was -1.7 vs -1.4 in the same arms ( $p \geq 0.05$ for all), (figure 1).

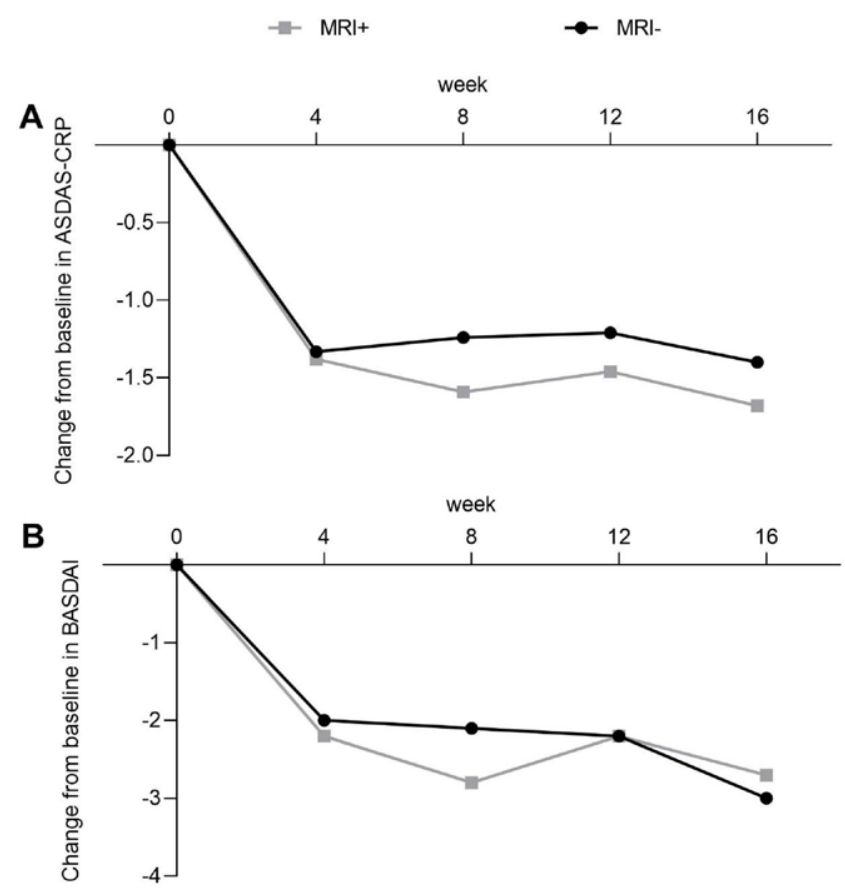

Figure 1. Clinical improvements in AS disease activity. Mean change from baseline is shown for (A) ASDAS-CRP, and (B) BASDAI

Conclusion: NTK leads to decline of disease activity in AS pts irrespectively of sacroiliitis on MRI.

REFERENCES:

[1] Rudwaleit M, et al. MRI in predicting a major clinical response to anti-tumour necrosis factor treatment in ankylosing spondylitis. Ann Rheum Dis 2008;67(9):1276-81.

[2] Sieper J, et al. A randomized, double-blind, placebo-controlled, sixteen-week study of subcutaneous golimumab in patients with active nonradiographic axial spondyloarthritis. Arthritis Rheumatol. 2015;67(10):2702-12.

Acknowledgements: This study was sponsored by JSC BIOCAD.

Disclosure of Interests: Inna Gaydukova Speakers bureau: Abbvie, Biocad Eli Lilly, MSD, Novartis, Pfizer, Sandoz, V Mazurov: None declared, Shandor Erdes: None declared, Tatiana Dubinina: None declared, Alena Kundzer: None declared, Nikolaj Soroka: None declared, Anna Eremeeva Employee of: Biocad

DOI: 10.1136/annrheumdis-2021-eular.2187

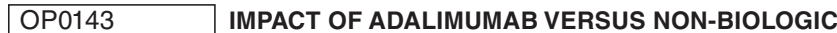 THERAPY ON DISEASE ACTIVITY AND PATIENT- REPORTED OUTCOMES IN ANKYLOSING SPONDYLITIS OVER 24 MONTHS - RESULTS OF THE COMPLETE-AS CANADIAN OBSERVATIONAL STUDY}

L. Bessette ${ }^{1}$, A. Chow ${ }^{2}$, V. Pavlova ${ }^{3}$, M. C. Laliberté ${ }^{4}$, M. Khraishi ${ }^{5} .{ }^{1}$ Laval University, Centre Hospitalier de l'Université Laval, Laval University, Centre Hospitalier de l'Université Laval, Quebec City, Canada; ${ }^{2}$ University of Toronto, University of Toronto, Toronto, Canada; ${ }^{3}$ McMaster University, McMaster University, Hamilton, Canada; ${ }^{4}$ AbbVie Corporation, AbbVie Corporation, Montreal, Canada; ${ }^{5}$ Memorial University of Newfoundland, Memorial University of Newfoundland, St. John's, Canada

Background: COMPLETE-AS was an observational study among Canadian biologic-naïve adults with active ankylosing spondylitis (AS) treated with either adalimumab or subsequent non-biologic disease-modifying anti-rheumatic drugs and/or non-steroidal anti-inflammatory drugs (nbDMARD/NSAID) after having switched from initial treatment with a preceding nbDMARD and/ or NSAID due to lack of response or intolerance, as per treating physician judgement. 